\title{
Modeling the Major Ailments of Petroleum Workers with Associated Risk Factors using Logistic Regression Approach
}

\author{
K.G.D.P. Gunarathne ${ }^{1}$, A.M.C.H. Attanayake ${ }^{2}$, D.D.M. Jayasundara ${ }^{3}$ \\ ${ }^{1,2,3}$ Department of Statistics \& Computer Science, University of Kelaniya, Dalugama, Kelaniya, Sri Lanka
}

\begin{abstract}
Petroleum workers directly expose to both petroleum vapors and liquid petroleum products. Long-term exposures to the petroleum products have been shown to affect functioning of different systems of the body. The effects may result in accelerated decline in lung functions, increase in skin rashes, increase in visual problems and increase graying hair. This study was aimed to model the major ailments; Cough, Visual Problem, Skin Rash and Graying Hair with associated risk factors; Age, Service, Use of Gasmask, Use of Goggles, Use of Gloves, Use of Cigarette, Use of Alcohol and Having Animals. Data were collected from a 90 petroleum workers, of one of the main petroleum storing and distributing centres of Sri Lanka. The analysis was carried out using binary and ordinal logistic regression. From the fitted logistic regression models, it can be concluded that the long-term exposure to the petroleum products causes bad health effects on petroleum workers. Further, based on the results it could conclude that safety wears help to prevent from that ailments.
\end{abstract}

Keywords: Ailments, Logistic Regression Models, Petroleum Products, Petroleum Workers, Risk Factors.

\section{Introduction}

With urbanization and rapidly increasing number of automobiles in Sri Lanka, there is an increase in the demand for petrol and diesel. Further, due to industrialization other petroleum products also have a higher demand. Therefore, in the storing and distributing centers of petroleum products, there is an increase in the occupational exposure to petroleum vapors among petroleum workers. Numerous epidemiological studies have documented decrements in pulmonary function and various other health problems associated with long-term air pollution exposure. There are also convincing evidences for an association between air pollution and cardiovascular disease.

One of the petroleum storing and distributing centres in Sri Lanka was selected for the study. Workers exposed to petroleum vapors and touch with liquid petroleum products during their working hours. Further, workers can work till the age 60 in the centre. Therefore, some of the workers have worked more than 10 years, more than 20 years and some have worked more than 30 years. Long-term exposure to petrol vapor has shown to affect the different physiological systems in the body. While working in some projects of this centre most of the workers has mentioned about the deaths of filling workers after a few months of their retirement. Therefore, there is a thought in minds of lot of workers such that working as a filler, cause dangerous health effects. However, due to high wage that paid to fillers most of the people prefer to join as a filler in this centre. In this centre they supply safety wears such that helmets, gloves, gas masks, boots and uniforms to all fillers. These safety wears help them to protect their hands, feet and body from touching oil products. In addition to that, safety wears help to protect their breath from vapor of oil products. But we can observe that most of them are not wearing these safety wears. As the reasons of not wearing safety wears they indicate that when wearing gasmask, it is very difficult to breathe and it cause sweat, wearing goggles and gloves also not comfortable when doing works and etc. However, it can affect to their health badly.

Therefore, this study was aimed to model the major ailments, which are Cough, Visual Problem, Skin Rash and Graying Hair with associated risk factors, which are Age, Service, Use of Gasmask, Use of Goggles, Use of Gloves, Use of Cigarette, Use of Alcohol and Having Animals.

\section{Methods/ Approach}

This research was conducted on ailments of petroleum filling workers. Research data were collected using a questionnaire and by direct interviews. Study group of this study was 90 petroleum workers, of one of the main petroleum storing and distributing centres of Sri Lanka.

The descriptive statistics was carried out to get the frequencies of each ailment to find out the ailments that majority of them are suffering from. From those frequencies, if more than $50 \%$ of the workers are suffering from any disease, it was selected for the study. Then cross tabulation with chi-square tests was carried out for all independent variables such that Age, Service, Use of Gasmask, Use of Goggles, Use of Gloves, Use of Cigarette, Use of Alcohol and Having Animals to find out what factors are statistically significantly associated with each ailment at $5 \%$ significance level. Influence of the factors to the ailments are identified using odds and relative risk values. All the response and independent variables are categorical variables. Therefore, logistic regression was used to analyze the primary data. When the response variable is dichotomous, binary logistic regression was carried out and when the number of categories in response variable is greater than two and categories are in an ordinal scale, ordinal logistic regression was carried out. 


\section{International Journal of Science and Research (IJSR) \\ ISSN (Online): 2319-7064}

Index Copernicus Value (2013): 6.14 | Impact Factor (2015): 6.391

\section{Results \& Discussion}

From the questionnaires filled by petroleum filling workers, 18 ailments of filling workers have identified. But for the logistic regression analysis only four ailments were selected as majority of the workers are suffering from. Majority was identified using frequency tables such that if more than 50\% of the workers are suffering from any disease.

Table 1: Summary of suffering percentages

\begin{tabular}{|c|c|c|c|}
\hline Ailment & $\begin{array}{c}\text { Suffering } \\
\text { percentage }\end{array}$ & Ailment & $\begin{array}{c}\text { Suffering } \\
\text { percentage }\end{array}$ \\
\hline Cough & $65.6 \%$ & Skin rash & $51.1 \%$ \\
\hline Shortness of breath & $47.8 \%$ & Skin drying & $17.8 \%$ \\
\hline Asthma & $31.1 \%$ & Numbness & $38.9 \%$ \\
\hline Headache & $44.4 \%$ & Hair loss & $31.1 \%$ \\
\hline Stomachache & $35.6 \%$ & Graying hair & $80 \%$ \\
\hline Backache & $21.1 \%$ & Lung infection & $2.2 \%$ \\
\hline Gastritis & $17.8 \%$ & Liver problem & $20 \%$ \\
\hline Eye pain & $21.1 \%$ & Renal calculi & $20 \%$ \\
\hline Visual problem & $56.7 \%$ & Kidney injury & $1.1 \%$ \\
\hline
\end{tabular}

Table 1 shows more than $50 \%$ of workers are suffering from cough and it has chosen as a response variable for the logistic regression analysis. Likewise, from all 18 -frequency tables it could chose only four ailments for logistic regression analysis due to the more than $50 \%$ is not appeared in other ailments. Therefore, major ailments are cough, visual problem, skin rash and graying hair. But over $40 \%$ of workers are suffering from shortness of breath and headache also. Therefore, since these two ailments also very near to the $50 \%$ further analysis should consider about them.

Table 2 shows how the variables are categorized into categories and meanings of each variable.

Table 2: Data Representation

\begin{tabular}{|c|c|}
\hline Variable Name & Label \& Values \\
\hline Age & $\begin{array}{c}\text { Age category }(1=" 31-40 ", 2=" 41-50 ", 3=" 51- \\
60 ")\end{array}$ \\
\hline Gloves & $\begin{array}{c}\text { Does the respondent wear gloves? }(0=" \text { No", } \\
1=" Y e s ")\end{array}$ \\
\hline Goggles & $\begin{array}{c}\text { Does the respondent wear goggles? }(0=" N o ", \\
1=" Y e s ")\end{array}$ \\
\hline Gasmask & $\begin{array}{c}\text { Does the respondent wear gasmask? }(0=" N o ", \\
1=" Y e s ")\end{array}$ \\
\hline Cough & $\begin{array}{l}\text { How often the respondent suffer from cough? } \\
(0=\text { "No", } 1=\text { ="Rarely", } 2=\text { ="Normally", } 3=\text { ="Often") }\end{array}$ \\
\hline Visual_problem & $\begin{array}{l}\text { Does the respondent suffer from visual problem? } \\
(0=" N o ", 1=" Y e s ")\end{array}$ \\
\hline Skin_rash & $\begin{array}{l}\text { Does the respondent suffer from skin rash? } \\
\qquad(0=" N o ", 1=" Y e s ")\end{array}$ \\
\hline Alcohol & $\begin{array}{l}\text { Has the respondent used alcohol? }(0=\text { "No", } \\
1=\text { "Yes") }\end{array}$ \\
\hline Cigarette & $\begin{array}{c}\text { Has the respondent used cigarette? }(0=" N o ", \\
1=" Y e s ")\end{array}$ \\
\hline Animal & $\begin{array}{c}\text { Does the respondent have animals? }(0=" \text { No", } \\
1=" Y e s ")\end{array}$ \\
\hline Working_years & $\begin{array}{c}\text { Number of years that the respondent has worked } \\
\text { in filling staff of CPSTL }\end{array}$ \\
\hline Service_Cat & 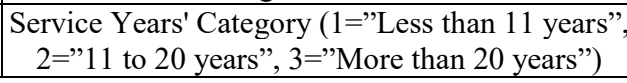 \\
\hline
\end{tabular}

The associations between independent variables and dependent variable was tested using cross tabulation with chi-square test at 5\% significance level. If there is a statistically significant association of any independent variable with response variable at 5\% significance level, then that independent variable can be selected for logistic regression model. The selected variables are shown in Table 3.

Table 3: Summary of Associations

\begin{tabular}{|c|c|c|}
\hline $\begin{array}{l}\text { Dependent variable } \\
\text { (Response Variable) }\end{array}$ & $\begin{array}{l}\text { Included risk } \\
\text { factors }\end{array}$ & $\begin{array}{l}\text { Associated risk } \\
\text { factors }\end{array}$ \\
\hline Cough & $\begin{array}{l}\text { - Gasmask } \\
\text { - Cigarette } \\
\text { - Animal } \\
\text { - Bird } \\
\text { - Service }\end{array}$ & $\begin{array}{l}\text { - Gasmask } \\
\text { - Cigarette } \\
\text { - Animal } \\
\text { - Service }\end{array}$ \\
\hline Visual problem & $\begin{array}{l}\text { - Age } \\
\text { - Goggles } \\
\text { - Alcohol } \\
\text { - Service }\end{array}$ & $\begin{array}{l}\text { - Age } \\
\text { - Goggles } \\
\text { - Alcohol } \\
\text { - Service }\end{array}$ \\
\hline Skin rash & $\begin{array}{l}\text { - Gloves } \\
\text { - Cigarette } \\
\text { - Animals } \\
\text { - Birds } \\
\text { - Service } \\
\end{array}$ & $\begin{array}{l}\text { - Gloves } \\
\text { - Service }\end{array}$ \\
\hline Graying hair & $\begin{array}{l}\text { - Age } \\
\text { - Helmet } \\
\text { - Service }\end{array}$ & $\begin{array}{l}\text { - Age } \\
\text { - Service }\end{array}$ \\
\hline
\end{tabular}

According to the categories of response variable, analyzing methods were selected as follows:

Table 4: Model Selection

\begin{tabular}{|c|c|c|}
\hline $\begin{array}{c}\text { Response } \\
\text { Variable }\end{array}$ & $\begin{array}{c}\text { Categories of } \\
\text { Response Variable }\end{array}$ & Analyzing Method \\
\hline \multirow{2}{*}{ Cough } & $\begin{array}{c}\text { =="No", 1="Rarely", } \\
\text { 2="Normally", } \\
\text { 3="Often" }\end{array}$ & $\begin{array}{c}\text { Ordinal Logistic } \\
\text { Regression }\end{array}$ \\
\hline Visual Problem & 0="No", 1="Yes" & Binary Logistic Regression \\
\hline Skin Rash & 0="No", 1="Yes" & Binary Logistic Regression \\
\hline Graying Hair & 0="No", 1="Yes" & Binary Logistic Regression \\
\hline
\end{tabular}

Models have fitted using both methods forward stepwise (likelihood ratio) and backward stepwise (likelihood ratio), and then found the best model according to the greater value of pseudo R squared and greater value of Area Under the ROC Curve.

According to the classification table of ordinal logistic regression model for the response variable cough, cases in category two (rarely cough) are more likely to be classified as category one than category two and category four (often cough) cases are somewhat poorly predicted, with the majority of cases being assigned to category three (normally cough), a category that should theoretically be dissimilar to category four. This may indicate a problem in the way the ordinal outcome scale is defined. Therefore, by merging categories one and two together as 'Having no cough' and categories three and four together as 'Having cough', dependent variable became dichotomous and binary logistic approach was considered. 
Fitted Best Logistic Regression Models

3.1.1 Binary Logistic Regression Model for the Response Variable Cough

$\operatorname{Logit}(\mathrm{p})=-2.881-$

$1.467 *$ Gasmask $(1)+2.483 *$ Cigarette $(1)+1.429 *$ Service_Cat (

2) $+2.842 *$ Service_Cat $(3)$

\subsubsection{Binary Logistic Regression Model for the Response} Variable Visual Problem

$\operatorname{Logit}(\mathrm{p})=-2.616+1.637 * \operatorname{Age}(2)$

$0.075 *$ Age $(3)+1.375 *$ Alcohol(1)+1.351*Service_Cat(2)+3.3 $61 *$ Service_Cat $(3)$

\subsubsection{Binary Logistic Regression Model for the Response} Variable Skin Rash

$\operatorname{Logit}(\mathrm{p})=-$

$1.435+0.993 *$ Service Cat $(2)+2.688 *$ Service Cat $(3)$

\subsubsection{Binary Logistic Regression Model for the Response Variable Graying hair}

$\operatorname{Logit}(\mathrm{p})=-$

$0.284+1.826 * \operatorname{Age}(2)+0.306 * \operatorname{Age}(3)+1.721 *$ Service Cat $(2)+$

$2.717 *$ Service_Cat $(3)$

There is a negative relation from gasmasks to the ailment cough, which indicates that when using gasmask, it helps to prevent from cough (not having cough). Gasmasks help to save their breath from petroleum vapor. Service years' categories also positively related with having cough, which indicates that when the number of service years are increasing risk of having cough is also increasing.

From the results of visual problem, it shows that when number of service years are greater than 10, percentage of people having visual problem has increased. When number of service years are greater than 20, risk of having visual problem is higher than the people whose service years are less than 20 .

When considering on skin rash, negative relation between gloves (safety wear) and skin rash implies that if the workers are using gloves they can prevent from skin rashes. Then the next factor, number of service years. The effect from the number of service years to the ailment skin rash is not different from the above two ailments. When number of service years are greater than 10, percentage of people having skin rash has increased. When number of service years are greater than 20, risk of having skin rash is higher than the people whose service years are less than 20 .

Then the last problem, which is graying hair, is more common problem inside the company. It also has positive relations with the number of service years, which means when the number of service years is increasing, risk of having graying hair is also increasing.

\section{Future Scope}

According to the above discussed results, for the increment of healthiness of workers', suggestions can be made up for the company side as making a rule of wearing safety wears while doing filling works is essential.
Since the number of service years affect to the all ailments such that when the number of service years is more than 10 years, there is an increased risk in each ailment, it can suggest to limit the service period of a filling worker into 10 or 15 years.

And another suggestion can be made up to do a medical examination of each filling worker once in a five years' period to identify whether they are in a good health condition to continue their job as a filling worker.

A suggestion can be made up on filling workers to wear all safety wears while doing petroleum-filling works for their sanitation.

\section{Conclusion}

According to the logistic regression equation, there is a negative relationship between variables 'using gasmask' \& 'having cough' which indicates that people who are using gasmasks are less likely to suffer from cough than people who are not using gasmask as a safety wear, i.e. safety wears helps to prevent from cough. In addition, there is a positive relation between variables 'Service years greater than 20' \& 'having cough'. This indicates that when service years are increasing, people are more likely to suffer from cough than whose service less than 11 years.

There is a positive relation between variables 'Service years between 11 to $20^{\prime}$ \& 'having visual problem'. Moreover, there is a positive relation between variables 'Service years greater than 20 ' \& 'having visual problem'. This indicates that when service years are increasing, people are more likely to suffer from visual problem than whose service less than 11 years.

According to the logistic regression equation, there is a negative relation between variables 'using gloves' \& 'having skin rash' which indicates that, people who are using gloves are less likely to suffer from skin rash than people who are not using gloves as a safety wear, i.e. safety wears helps to prevent from skin rash. In addition, there is a positive relation between variables 'Service years between 11 to 20 ' \& 'having skin rash'. In addition, there is a positive relation between variables 'Service years greater than 20' \& 'having skin rash'. This indicates that when service years are increasing, people are more likely to suffer from cough than whose service less than 11 years.

There is a positive relation between variables 'Service years between 11 to 20 ' \& 'having graying hair'. Moreover, there is a positive relation between variables 'Service years greater than 20 ' \& 'having graying hair'. This indicates that when service years are increasing, people are more likely to suffer from graying hair than whose service less than 11 years.

Therefore, finally it can conclude that there is a good effect from safety wears to the ailments such that when using safety wears, it helps to prevent from ailments, which are caused due to the exposure of petroleum products. Further, when the number of service years are increasing, it affects functioning of different systems of the body such as lung functions, skin, eye and hair of workers badly. 


\section{International Journal of Science and Research (IJSR) \\ ISSN (Online): 2319-7064}

Index Copernicus Value (2013): 6.14 | Impact Factor (2015): 6.391

\section{References}

[1] Aksoy, M. (1989). Hematotoxicity and Carcinogenicity of Benzene. Environmental Health Perspectives, 193197.

[2] Alam, R., Zafar, A., Ghafoor, A., Naseem, A., Ali, Q., \& Imtiaz, F. (2014). Lung Function Abnormalities Among Fuel Filling Workers in Karachi, Pakistan. Pinnacle Environmental \& Earth Sciences, 1-5.

[3] Ari, E., \& Yildiz, Z. (2014). Parallel Lines Assumption in Ordinal Logistic Regression and Analysis Approaches. International Interdisciplinary Journal of Scientific Research, 8-23.

[4] Bayaga, A. (2010). Multinomial Logistic Regression: Usage and Application in Risk Analysis. Journal of Applied Quantitative Methods, 288-297.

[5] Begum, S., \& Rathna, M. B. (2012). Pulmonary function tests in petrol filling workers in Mysore city. Mysore Medical College \& Research Institute, 12-14.

[6] Chung, K. F., Widdicombe, J., \& Boushey, H. (2003). Cough: Causes, Mechanisms and Therapy. Blackwell.

[7] Dust Allergy. (2015, 10 22). Retrieved from American College of Allergy, Asthma \& Immunology: http://acaai.org/allergies/types/dust-allergy

[8] Garrity, J. (2015, 12 03). MSD MANUALS. Retrieved from Effects of Aging on the Eyes: http://www.msdmanuals.com/home/eyedisorders/biology-of-the-eyes/effects-of-aging-on-theeyes

[9] Hu, B., Shao, J., \& Palta, M. (2006). Pseudo- $\mathrm{R}^{2}$ in Logistic Regression Model. Statistical Sinica, 847-860.

[10] Kanezaki, M., Ebihara, S., Gui, P., Ebihara, T., \& Kohzuki, M. (2012). Effect of cigarette smoking on cough reflex induced by TRPV1 and TRPA1 stimulations. Respiratory Medicine, 406-412.

[11] Pet Allergy. (2015, 10 22). Retrieved from Mayo Foundation for Medical Education and Research: http://www.mayoclinic.org/diseases-conditions/petallergy/basics/symptoms/CON-20028932

[12] Raabe, G. K., \& Wong, O. (1996). Leukemia mortality by cell type in petroleum workers with potential exposure to benzene. Environmental Health Perspectives, 1381-1392.

[13] Sahb, A. A. (2011). Hematological assessment of gasoline exposure among petrol filling workers in Baghdad. Fac Med Baghdad, 50-62.

[14] Schnatter, A. R., Glass, D. C., Tang, G., Irons, R. D., \& Rushtan, L. (2012). Myelodysplastic Syndrome and benzene exposure among petroleum workers: An International Pooles Analysis. JNCI, 1724-1737.

[15] Sirdah, M. M., A Laham, N. A., \& Madhoun, R. A. (2011). Possible health effects of liquefied petroleum gas on workers at filling and distribution stations of Gaza governorates. Al Azhar University, Gaza, Palastine, 289-294.

[16] Sweet, S. A., \& Martin, K. G. (n.d.). Multivariate Analysis with Logistic Regression. In Data Analysis with SPSS - A First Course In Applied Statistics (pp. 157-166). Boston: AB.

[17] Uzma, N., Salar, B. M., Kumar, B. S., Aziz, N., David, M. A., \& Reddy, V. D. (2008). Impact of organic solvents \& environmental pollutants on the physilogical function in petrol filling workers. Environmental Research and Public Health, 139-146.

[18] W, J. (2006). Bringing balance and technical accuracy to reporting odds ratios and the results of logistic regression analyses. A peer-reviewed electronic journal, 1-6.

\section{Author Profile}

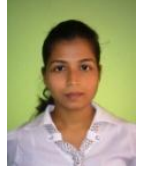

K. G. Dinusha Prasadi Gunarathne received the B.Sc. Special degrees in Statistics from University of Kelaniya, Sri Lanka in 2016. She now working in the Department of Statistics \& Computer Science, University of Kelaniya, Sri Lanka. 